\title{
Familia eta hiperaktibitatea elkarrekin biziz: atxikimendua eta heziketa-estiloak
}

\author{
Goretti Soroa Martinez, Lorena Revert Sánchez, Aitor Aritzeta Galan \\ Euskal Herriko Unibertsitatea (UPV/EHU)
}

\begin{abstract}
Arreta Gabezia eta Hiperaktibitatea Nahastea (AGHN) haurren artean maiztasun handienarekin diagnostikatzen den nahastea da, horren prebalentzia \% 6.7 eta $\% 7.8$ artean dagoelarik mundu mailan. AGHNa diagnostikatzeko bi sailkapensistema dira ezagunenak: DSM-V (APA, 2014) eta CIE-11 (OMS, 2018). Horien arabera, nahasteak jatorri neurobiologikoa du eta familia zein eragile sozialek ardura nabarmena dute berarengan. Honenbestez, lan honen helburua hirukoitza da. Batetik, AGHNaren kontzeptualizazio, sintomatologia eta ebaluazioaren inguruko informazioa eguneratu nahi da, berrikuspen bibliografiko baten bitartez. Bestetik, familia-sistemak AGHNan duen papera aztertuko da, hain zuzen, bai gurasoen heziketa-estiloek, bai atxikimendu mota ezberdinek diagnostikoan duten eragina. Azkenik, ikuspegi teoriko batetik aplikatuago batera salto eginez, AGHNa duten haurren familiakideentzat lagungarriak izan daitezkeen esku-hartze proposamenak luzatuko dira; zehazki, arlo emozionalean, kognitiboan, konduktualean eta sozialean.
\end{abstract}

GAKO-HITZAK: AGHNa · Haurtzaroa · Familia-sistema · Atxikimendua · Heziketa-estiloak.

\section{Family and hyperactivity living together!: attachment and education styles}

Attention Deficit Hyperactivity Disorder (ADHD) is the most prevalent disorder diagnosed in childhood, in fact, its worldwide prevalence is estimated among \%6.7 and \%7.8. Based on the current two international classification systems for diagnosing ADHD (DSM-5; APA, 2014 and CIE-11; OMS, 2018), it is considered to have a neurobiological basis and that other factors such as family and other social agents may have an impact on this disorder. The purpose of this study is threefold. On the one hand, we will make an approach to the conceptualization, symptomatology and evaluation sistems of ADHD, through a literature review. On the other hand, we will analyze the role of the family in this disorder, taking into account the parenting styles, as well as the effect that diverse emotional attachments can have in the diagnosis. Lastly, moving from a theoretical part to a more practical one, some proposals for action will be presented with the aim of helping children with ADHD and their families in the emotional, cognitive, behavioral and social areas.

KEY WORDS: ADHD · Childhood · Family system · Attachment · Education styles. 


\section{Sarrera}

Gaur egun, Arreta Gabezia eta Hiperaktibitatea Nahastearen (AGHNa) diagnostikoa haurren artean maiztasun handienarekin ematen den nahaste mentala da, gainera, osasun mentaleko zerbitzuetara jotzeko arrazoi nagusietarikoa da. Nahaste honen prebalentziari dagokionez, duela gutxi egindako berrikuspen sistematiko baten arabera, \% 6.7 eta \% 7.8 tartean kokatzen dela estimatzen da (Thomas, Sanders, Doust, Beller eta Glasziou, 2015). Gainera, urtetik urtera diagnostikoen kopurua igotzen ari da, batez ere mutilen artean (Londoño, 2017). AGHNak interes sozial handia piztu du azken urteotan, besteak beste, faktore hauek direla-eta: diagnostikatuen prebalentzia altua, psikofarmakoen erabilera, eta hainbat testuingururekiko inpaktua (familia, lagunartea, ikastetxea).

Tratamendu gisa farmakoak erabili ohi dira maiz, zeintzuek albo-kalteak eragiten dituzten, bereziki haur txikien garapenean. Horien artean, suminkortasunaren areagotzea, buruko mina, umorean aldaketak, inhibizioa, lotarako arazoak eta jateko gogoaren galera aurkitzen dira. Aipatutako albo-kalteek tratamendurako beste aukera batzuk bilatzera eramaten gaituzte (Siegenthaler, Presentación, Colomer eta Miranda, 2013).

Beraz, gai honek gaur egun duen interesa ikusita eta AGHNaren tratamenduan dagoen hutsunea betetzeko asmoz, «Familia eta hiperaktibitatea elkarrekin biziz: atxikimendua eta heziketa-estiloak» izenburua duen lan hau proposatzen da, zeina hiru zati nagusitan banatzen den. Lehenik eta behin, sarrera gisa, AGHNaren inguruko informazioa aurkezten da, haren kontzeptualizazioa, sintomatologia eta ebaluazioa barne harturik. Ondoren, ikuspegi sistemikoaren garrantziaz arituko gara, bereziki, gurasoek bertan atxikimendu-irudi bezala eta hezitzaile gisa duten rolean zentratuz. Horrela, zaintzaileekiko gertutasuna bilatzearen eta testuinguruaren esplorazioaren arteko oreka bat bermatuz haurraren garapen-prozesuan (Ainsworth, 1979). Eta azkenik, nahaste honen tratamendurako familiaren zeregina azpimarratuko da, jada abian diren esku-hartze programa ezberdinen eraginkortasuna aipatuz. Lan honi amaiera emateko asmoz eta zati teorikoan ikusiko diren edukietan oinarrituz, AGHNa duten haurren gurasoei zuzendutako proposamen batzuk luzatuko dira.

Gaiaren inguruko errebisio sistematikoa PRISMA prozedurarekin burutu da, honako datu-base hauek erabili direlarik: ISI Web of Knowledge, PLOS, PsycINFO, Psicodoc, Psycarticles, MEDLINE, PubMed eta Dialnet. Artikuluen aukeraketarako arreta, hiperaktibitatea, inpultsibitatea, seme-alabak, gurasoak, irakasleak, ebaluazioa, tratamendua eta eraginak hitzak erabili dira, bai ingelesez baita gaztelaniaz ere.

\section{Arreta Gabezia eta Hiperaktibitatea Nahastea (AGHN)}

\subsection{AGHNaren kontzeptualizazioa}

Elkarte Psikiatriko Amerikarrak (APA, 2014) eta Osasunaren Mundu Erakundeak (OMS, 2018) argitaratu ohi dituzten nahaste mentalen inguruko sailkapenen arabera (DSM eta CIE hurrenez hurren), AGHNak oinarri neurobiologikoa du. Gainera, 
eguneroko jarduerak nahiz akademikoak egiteko ezintasuna edo zailtasunak nabarmentzen dira eta bulkadak kontrolatzeko ezintasunarekin batera ageri ohi da. Gaitz honek arlo sozialean eta psikologikoan ondorio nabarmenak ditu. Horrela, nahaste hau pairatzen duen pertsonaren bizitzan zein haren familian edo ingurukoetan eragin handia du. Garapenaren aro goiztiarretan hiru eta sei urte bitarteko haurrekin egindako ikerketetan ondorio adierazgarriak aurkitu dira eskola-errendimenduan eta familia-osasunean; izan ere, bi horien kalitatea AGHNdun familietan kaskarragoa dela ikusi da (Canals, Morales-Hidalgo, Jané eta Domènech, 2018).

Esan bezala, nahiz eta oinarri biologikoa duen nahaste gisa kontsideratua izan, ukaezina da gaitz honen agerpenean eta garapenean testuinguruko faktoreek duten garrantzia. Beraz, nahastearen etiologia azaltzen duten hainbat teoria daude, funtsean, neurokognitiboak nahiz ingurumen-teoriak. Lehenengo teorien arabera, burmuineko neokortex frontalean nagusi diren funtzio exekutiboen errendimendu baxuak nahastea azaldu dezake. Motibazio-falta edota prozesamendu tenporaleko defizit batetik ere eratorria izan daiteke. Teoria neurobiologikoek dopaminaren gene garraiatzailearen garrantzia ere azpimarratu izan dute. Baina azalpen horiek ez dute gaitz honen sintomen bariantza osoa argitzen (Roskam et al., 2014).

Testuinguruko faktoreen garrantzia azpimarratzen duten teoriek ere nahastearen jatorria azaltzen dute. Ezaugarri kulturalek nahiz familia-testuinguruek eragina dute. Bigarrenei dagokienez, bikote-arazoak, maila soziokultural baxua eta delinkuentzia agertzen diren familietan AGHNa maiztasun handiagoarekin ikusi izan da (Roskam et al.,2014). Bestetik, familia-testuinguruan suertatzen diren beste bi alderdik ere nahastean eragina dutela ikusi izan da, hala nola atxikimendu-harremanek eta heziketa-estiloek (Rygaard, 2008).

Atxikimenduari dagokionez, AGHNan kaltetuak egon ohi diren hainbat gaitasunen garapena ahalbidetu dezake atxikimendu ziurra izateak. Aldiz, atxikimendu ezziurra duten familia-sistemetan nahaste honetan ikusten diren hainbat sintoma mantendu edo indartu daitezke. Gainera, gainontzeko lagin ez-klinikoarekin alderatuz, atxikimendu ez-ziurra duten familietan AGHNaren tasa altuagoa dela ikusi izan da (Santurde eta Del Barrio, 2013). Heziketa-estiloen inguruan, aldiz, heziketa-estilo ezegokiak (permisiboa, autoritarioa eta axolagabea) oinarri dituzten familietan nahastearen sintomatologia areagotzen dela ikusi da; demokratikoan, aldiz, estilo ezegokiekin alderatuz, sintomatologiaren pronostikoa hobea dela aurkitu da (Muñoz, Lago eta Sánchez, 2017). Hori horrela izanik ere, bi aldagai hauetan (heziketa-estiloak eta atxikimendua) oinarritzen diren esku-hartzeen kopurua urria da (Santurde eta Del Barrio, 2013).

\subsection{AGHNaren sintomatologia}

AGHNak hiru mota barne hartzen ditu: arreta-gabezia, hiperaktibitate/ inpultsibitatea eta konbinatua (ikus eranskina; DSM-V, APA, American Psychiatric Association, 2014). Arreta-gabezia zereginei jarraitzeko ezintasunean islatuta ikusten da, bertan badirudi haur hauek esaten zaiena aintzat hartzen ez dutela eta maiz haien material pertsonalak galtzen dituztela. Bestetik, hiperaktibitate-inpultsibitateak gehiegizko jarduera, mugimendu urduriak, denbora-tarte batez eserita egoteko 
zailtasuna, beste pertsonen kontuetan muturra sartzeko joera eta zerbaiten zain egoteko ezintasuna dakartza.

\section{Arreta-gabezia nagusi duen nahastea}

Hiperaktibitate-ezagatik bereizten da. Maizago agertzen da nesken artean, orokorrean kasuen \% 25 azpimota honetakoa da (Cornejo, Fajardo, López, Soto eta Ceja, 2015). Haur hauek egunerokotasuneko zereginak antolatzeko eta lehentasunordenak ezartzeko zailtasunak izan ohi dituzte. Arretari dagokionez, esan daiteke arreta selektiboan aurkitzen direla gabezia nabarmenenak, lan-oroimenerako arazoak dituzte ere eta makaltasun pertzeptibo zein mugimenduzkoa agertzen dute.

Arreta-gabezia hiperaktibitaterik eta gehiegizko inpultsibitaterik gabe duten haurrak apatikoak izan ohi dira, esna amets egiten dute, eginkizunak ez dituzte amaitzen, barnerakoiak dira, jendartean bakartuak agertzen dira eta depresioa nahiz barne-herstura gehiagotan aurkezten dute, hiperaktibitatea dutenekin alderatuta. Gainera sintoma hauek eskola-errendimendu txarrarekin batera ageri dira maiz. Sintoma hauek guztiak barnerakoiak direnez, sarritan diagnostikatu gabe gelditzen dira eta ez dute beharrezko laguntzarik jasotzen.

\section{Hiperaktibitatea-inpultsibitatea nagusi duen nahastea}

Portaera hiperaktiboa eta inpultsiboa agertzen dute. Azpimota honek \% 15 hartzen du (Cornejo et al., 2015) eta Haur Hezkuntzako haurrengan aurkitu izan da batez ere. Haur hauek inpultsiboagoak dira, etengabe mugitzen dira, dena ukitzen dute. Lehen Hezkuntzan, ikaskuntza sistematikoari ekin behar diotenean arretazailtasunak nabarmentzen hasten dira: ardura gabeko idazkera, lan narrasak, ez dute entzuten, argibideei ez diete jarraitzen, etab.

Bulkadak berehala asebetetzera zuzendutako portaera edo inpultsibitatea inhibitzeko zailtasuna dira ezaugarri nagusiak. Haur hauen portaera desinhibituak besteen bazterketa eragin dezake eta harreman sozialak zaildu egiten ditu. Kideen artean baztertuak aurkitzera eraman ditzake eta horrek, aldi berean, euren buruen irudi negatiboa edukitzera.

\section{Arreta-gabezia, hiperaktibitatea eta inpultsibitatea konbinaturik dituen azpimota}

Azpimota hau ohikoena da; izan ere AGHNa duten haurren \% 60 azpimota honen barnean kokaturik dago (Cornejo et al., 2015). Bertan aurreko bi taldeetan ageri diren sintomak konbinaturik agertzen dira. Etengabe mugimenduan egon beharra eta arreta mantentzeko arazoak dituzte. Sarritan, gainera, portaera erasokorrak eta agintearekiko aurkakotasuna ere aurkezten dituzte. AGHNa duten haur gehienek bi patroi klinikoak agertzen dituzte, beraz; AGHN konbinatua dute.

\subsection{AGHNa eta komorbilitatea}

AGHNarekin batera, aldi berean, nahaste bat edo gehiago ager daitezke. Horrela, haurren biztanleria ez-klinikoan barne-hersturaren tasa \% 5 ingurukoa den bitartean, AGHNa duten haurren artean \% 25ekoa da. AGHNa dutenen artean ugariagoak 
dira, baita ere, ezkortasun desafiatzailearen nahastea, nahaste disoziala, depresioa, Tourette-ren sindromea edo ikaskuntzaren nahasteak dituztenak.

\section{Ezkortasun desafiatzailearen nahastea}

AGHNa dutenen \% 40-60 inguruk etsaitasuna, eztabaidetarako joera, esanekotasunik eza eta autoritate-irudiekiko aurkakotasuna agertu ohi dituzte (Sadek, 2019). Autoritateari aurre egin ohi diote, helduen aginduak bete gabe utziz, besteei beldurra eraginez, errua botaz eta gizarte-arauak maiz apurtuz. Nahaste hau duten haurrak gatazka asko dituzten familietan gehiago agertzen dira, eta haien arazoak ez daude adimen-mailarekin hain zuzenki lotuak; portaera hertsatzaileen eta tenperamentu erasokorraren ereduan hobeto kokatzen dira. Kontrol-gabezia edo arreta-gabezia bezalako portaerak agertzen dituzte etsaitasun-egoeren baitan.

\section{Nahaste disoziala}

Gizarteko arauen apurketa garrantzitsuak, portaera erasokorrak (borrokan hasi, jipoitu) eta ez-erasokorrak (ostu, piper egin, gezurrak esan) ager ditzakete. Pertsonen oinarrizko eskubideak bortxatu eta arau sozial garrantzitsuak hautsi egin ditzakete (erasoak, lapurretak). AGHNa nahaste honekin konbinatzean, nerabeek desiratu gabeko portaerak gerta daitezke, hala nola haurdunaldiak, erailketak eta gazteen delinkuentzia. Nahaste disoziala duten haurren \% 90ek ezkortasun desafiatzailearen nahastea ere badu (Jusyte, Pfister, Gehrer eta Schönenberg, 2019). Hiperaktibitate goiztiarrak portaera antisozialak eragin ditzake nerabezaroan, baina aurrez normalki nahaste negatibista gertatu da. Nahaste disozialaren erasokortasuna AGHNarena baino pentsatuagoa da (Haranburu, Guerra, Torres eta Zumalabe, 2006).

\section{Depresioa}

AGHNa eta umore-egoeran nahasteak aldi berean gertatzen dira kasuen \% 1535etan (Sonuga-Barke, Cortese, Fairchild eta Stringaris, 2016). AGHNa dutenen \% 15-20 inguruk nahaste depresiboren bat agertzen du bere bizitzako uneren batean. Egile batzuen arabera, haur batzuei AGHNa diagnostikatu izan zaie, azpiko nahastea depresioa zenean. Beste egile batzuen arabera, sintoma depresiboak AGHNaren ondorenez sortutako porrotari eta desmoralizatzeari zor zaizkio. Haranburu eta haren ikerkideen (2006) arabera, haurrak AGHNa eta depresioa aldi berean dituenean, lehenik depresioa tratatu behar da, haur deprimituak ez baititu estimulatzaileak ongi jasaten, eta gainera, apetitua galdua du, ez du lo ongi egiten, haserrekor egoten da eta buruko minak izaten ditu.

\section{Barne-herstura nahasteak}

Haurren \% 20-25ek barne-herstura nahasteren bat aurkeztu ohi du AGHNarekin batera (González-Castro, Rodríguez, Cueli, García eta Álvarez, 2015). Ikerketa asko egin dira AGHNa eta barne-herstura komorbidoa dutenen tratamenduari buruz: estimulatzaileek albo-efektu kaltegarri gehiago dituzte barne-herstura dutenengan, eta haien lan-memoria ez da hainbeste hobetzen (McAuley, Crosbie, Charach eta Schachar, 2017). 


\section{Tourette-ren sindromea edo tiken nahastea}

Tourette-ren nahastea dutenen \% 70 inguruk AGHNa ere badu. Beraz, AGHNaren maiztasuna oso handia da Tourette-ren nahastea dutenengan eta nahaste horren maiztasuna altua da nahaste obsesiboa dutenengan. AGHNaren eta nahaste obsesibo konpultsiboaren aldiberekotasuna Tourette-ren nahastearen eta nahaste obsesibo-konpultsiboaren loturari zor dakioke (Rivera, 2016).

\section{Substantzien abusua}

AGHNa duten gazte askok kontsumitzen dituzte zigarroak, marihuana, alkohola eta drogak (Herrera eta De María, 2018). AGHNa duten nerabeen \% 40k substantziekiko mendekotasun- edo abusu-arazoak ditu.

\subsection{AGHNaren ebaluazioa}

AGHNaren ebaluazioa egin ahal izateko, iturri ezberdinen gaineko informazioa biltzea da gomendagarriena: haurra, familia, adiskideak eta eskola-arloko hezitzaileak. Ebaluazio-tekniken artean elkarrizketak, behaketak, galdetegiak eta proba neuropsikologikoak erabili ohi dira. Horien artean, badira batzuk AGHNa duten haurrei soilik pasatzen zaizkienak, beste batzuk haien testuinguruko pertsonei (eskola edo familia) eta alderdi bat baino gehiago barne hartzen dituztenak. Jarraian, AGHNaren ebaluaziorako gehien erabiltzen diren gidaliburuak eta tresnak laburki aurkeztuko dira (ikus 1. taula). Tresna bakoitzaren xehetasunak, itemak, erantzuneskala eta ezaugarri psikometrikoak ezagutzeko, ikus erreferentzien atala.

\section{1. taula. AGHNaren ebaluaziorako erreferentziazko gidaliburuak eta tresnak.}

\section{A) AGHNa ebaluatzeko irizpideen gidaliburuak}

DSM-V (APA, 2014). Buru nahasteen inguruko gidaliburu diagnostiko eta estatistikoa (Diagnostic and Statistical Manual of Mental Disorders). Gidaliburu honen arabera, gaitz honen baitan hiru sintoma nagusi aurkitzen ditugu: hiperaktibitatea, inpultsibitatea eta arreta-gabezia. Ez dira zertan hiru sintomak agertu haur berean. Sintomak haurrak 12 urteak bete aurretik agertu beharko dira. Sintoma hauen intentsitatea pertsona batetik bestera aldakorra da, horrela, intentsitatea kontuan harturik 3 azpimota ezberdin bereiz daitezke:

- Arreta-gabezia nagusi duen AGHNa.

- Hiperaktibitate-inpultsibitatea nagusi duen AGHNa.

- AGHN mota konbinatua.

- Badago beste laugarren azpimota bat, «AGHN zehaztugabea» deritzona, non arreta-gabezia, hiperaktibitate- eta inpultsibitate-sintomak agertzen diren. Hauek ez dituzte zehaztutako irizpideak betetzen. 
CIE-11 (OMS, 2018). Osasuneko gaitz eta arazoen nazioarteko sailkapen estatistikoa (International Statistical Classification of Diseases and Related Health Problem). Gidaliburu honetan AGHNa nahaste hiperzinetiko bezala ezaguna da. Nahastea diagnostikatu ahal izateko hiru sintomak agertu behar dira haurrak 7 urteak bete aurretik. Eta antsietatea edo gogo-aldarteari egotzitako beste nahasterik balego, AGHNaren diagnostikoa baztertuko litzateke. Beraz, esan daiteke gidaliburu honetan zehazten diren irizpideak DSM-V baino murriztaileagoak direla.

B) Irakasleei eta familiari zuzendutako galdetegiak

CONNERS-en eskala (Conners, 1989). Eskala hau 6-12 urte-bitarteko haurren gurasoentzat nahiz irakasleentzat prestatua dago. Arreta jarraitua, erantzunen abiadura, distrakzioei erresistentzia eta inhibiziorako gaitasuna neurtzen ditu. Bertan hiperaktibitatea neurtzeko 10 galdera ageri dira, horiei esker haur hiperaktiboen jarrera prototipikoak zehazten dira.

BARKLEY-ren familia- eta eskola-egoeren inguruko galdetegia (Barkley, 1990). Bi zati baliokide ditu, bat gurasoentzat eta beste bat irakasleentzat. Zehazki, Lehen Hezkuntzako ikasleen inguruko balorazioa egitera bideratzen da. Hainbat egoeratan agertzen diren jokabide-arazoak ebaluatzen dira. Bertan jokabide horien garrantzia zehaztu beharko dute 1etik 9ra doan eskala batean.

EACP: Portaera gatazkatsuen arloen galde-sorta // Escala de Áreas de ConductasProblema (García eta Magaz, 2000). Eskala honek bi aplikazio posible ditu, bat 4-12 urtebitarteko gurasoei zuzenduta eta bestea irakasleei. Haur-garapenaren alderdi desberdinetan agertzen diren arazoak identifikatzeko baliagarria da tresna hau: doikuntza soziala, eskolaerrendimendua, arreta eta antsietatea. Agresibitate-arazoak, eskola-errendimendu baxua, arreta edo hiperaktibitate, antsietate eta uzkurtasun sozialaren detekzio azkarra egiteko oso baliagarria da.

EDAH: AGHNaren ebaluazioa // Evaluación del Trastorno por Déficit de Atención con Hiperactividad (Farré eta Narbona, 2001). Tresna honen helburua AGHNaren bereizgarri nagusien eta gaitz honekin ager daitezkeen izaera-nahasteen neurketan datza. 6-12 urtebitarteko haurren ebaluazioa egiteko baliagarria da. 20 itemez osatua dago, non 10ek arreta-gabezia, hiperaktibitatea eta inpultsibitatea neurtzen duten eta beste 10ek portaeranahastea.

BROWNen AGNaren eskalak haur, guraso eta irakasleentzat (Brown ADD Scales for Children, Parents and Teachers) (Rucklidge eta Tannock, 2002). Brown-en 3-12 urtebitarteko haurrentzako AGNaren formulario diagnostikoa (Brown ADD Diagnostic Form for Children). Brown-en 12-18 urte-bitarteko haurren AGNaren formulario diagnostikoa nerabeentzat (Brown ADD Diagnostic Form for Adolescents).

SNAP-IV: Berrikusitako balorazio galde-sorta irakasle eta gurasoentzat // Rating Scale-Revised. SNAP-IV: Teacher and Parent Ratings Scale (Swanson, 2003). LH eta DBHko ikasleen gurasoek eta irakasleek betetzeko heterotxostena da. Bertan AGHNaren adierazle diren jokaeren agerpen eta gogortasuna ebaluatzen da. Bertan, arreta-gabezia, hiperaktibitate/inpultsibitate eta agresibitate aldagaiak neurtzen dira. 
BASC: Haur eta nerabeen portaeraren ebaluazio-sistema // Sistema de evaluación de la conducta en niños y adolescentes (Reynolds eta Kamphaus, 2004). Proba multidimentsional hau irakasleentzat nahiz gurasoentzat egina dago. Jokabide eta izaeraren hainbat alderdi neurtzen ditu. Bertan dimentsio positiboak (egokitzaileak) nahiz negatiboak (klinikoak) barne hartzen dira. Horien artean eskolarekiko jarrera negatibo, sentsazio berrien bilaketa, kontrol locus, somatizazio, estres, antsietate, depresio, egokitzapen, gaitasun sozial, harreman sozial eta autoestimu aldagaiak neurtzen dira. Zehazki, 3-18 urte-bitarteko haurrekin erabiltzeko prestatua dago.

C) Haurrei zuzendutako tresnak

CPT: Errendimendu jarraituaren Conners testa // Conners Continous Performance Test (Conners, 1994). Baliagarria da arreta-gabezia, distrakzioa eta inpultsibitatea bereizteko LH eta DBHko ikasleen artean, hots, AGHNa identifikatzeko. CPT laborategiko proba izanik, egoera naturalen simulazioak kanpo-baliotasuna (baliotasun ekologikoa) areagotzen du barne-baliotasunari eragin gabe. Bertan, arreta selektiboa nahiz sostenitua eta inpultsibitatea neurtzen dira.

EMTDA-H: Magallanesen AGHNaren ebaluazio-eskala // Escala Magallanes de Evaluación del Trastorno por Déficit de Atención con Hiperactividad (García, Magaz eta Sandín, 2000). Eskala hauek AGHN gaitzean bereizgarri diren sintomen agerpena ebaluatzeko baliagarriak dira. Horien artean, arreta-urritasunak, hiperaktibitatea, hiperkinesia, urritasun erreflexiboak eta inpultsibitatea aurki ditzakegu. Esan daiteke tresna nahiko zehatza dela $\mathrm{AGHNa}$ duten pertsonak ez duten horien artean diskriminatzeko. Tresna hau eskolan nahiz familian erabiltzeko prestatua dago 6-16 urte-bitarteko haurrekin.

D-2: Arreta-testa (Brickenkamp, 2002). Prozesamendu-abiadura, arreta selektiboa eta kontzentrazio mentala neurtzeko baliagarria da. Aplikazio-denbora mugatua du (8-10 min), non deuseztapen zeregin bat aurrera eraman behar den. Zehazki, 8 urtetik aurrerako haurrekin erabiltzeko prestatua dago.

WISC: Wechslerren adimen-eskalak (Wechsler, 2008). Nahiz eta proba honek haurraren gaitasun intelektualaren inguruko informazio orokorra adierazi, AGHNa identifikatzeko proba osagarritzat erabil genezake. Bertan, lan-oroimena neurtzeko «digituen» azpiproba aipagarri dugu, zeinean sekuentziazio, malgutasun kognitibo, alerta eta planifikaziogaitasunak ebaluatzen diren. 5-16 urte-bitarteko haurrekin erabiltzeko prestatua dago.

CARAS ezberdintasunen arreta-testa (Thurstone eta Yela, 2012). Partzialki ordenaturiko estimuluen arteko antzekotasunak eta ezberdintasunak antzemateko gaitasuna neurtzeko baliagarria da. Proba honen iraupena oso laburra da, 3 minutukoa hain zuzen ere. Test honetan pertzepzioa, arreta eta inpultsibitatea neurtzen dira bereziki. 6-18 urte-bitarteko haurrekin erabiltzeko prestatua dago.

AULA NESPLORA (Iriarte et al., 2016). Errealitate birtualeko tresna honetan ikasgela bat simulatzen da eta irakasle birtualak aurkeztutako 5 eginkizun (bisualak/auditiboak) bete behar dira, testuinguru eskolarrean ohikoak diren distrakzioak agertzen diren bitartean. Ekipo informatiko baten bidez erabiltzen da: errealitate birtualeko betaurrekoak, entzungailuak eta mugimenduen sentsoreak; 15-20 minututan aplika daiteke. Bertan, ikus-entzunezko arreta mantendua, inpultsibitatea, arreta galtzeko joera, jarduera motorra eta prozesamendu-abiadura neurtzen ditu. Tresna hau 6 eta 16 urte-bitarteko haur eta nerabeei zuzenduta dago. 


\section{AGHNa eta familia-sistema}

AGHNaren garapenean eta tratamenduan, gainontzeko nahaste eta gaixotasunetan bezala, testuinguruko faktoreek zeresan handia dute. Hortaz, bere osotasunean ulertu eta aztertzeko ezinbestekoa da ikuspegi sistemikoa aintzat hartzea. Ikuspegi horretatik, zenbait faktorek, hala nola familiak, lagunek, eskolak eta egoera sozioekonomikoak, pertsonengan duten eragina (zeharkakoa zein zuzena) aztertzen da. Faktore horiek pertsonen garapen psikologikoan onuragarri edo kaltegarri suerta daitezke, horrela, nahaste edo gaixotasun baten bilakaeran zein haren pronostikoan izugarrizko eragina izan dezakete (Emerson eta Bögels, 2017).

Hainbat autoreren ustetan, AGHNan agertzen den aniztasuna bi faktore hauen elkarrekintzaren emaitza gisa har genezake: genetika eta testuingurua. Nahaste honen \% 70-80 heredagarria dela uste da (Presentación, Pinto, Meliá eta Miranda, 2009), baina haren adierazpena eta garapena ulertu ahal izateko, ezinbestekoa litzateke gaitzaren inguruko sistema sozialak aintzat hartzea.

Bronfenbrenner (1987) adituaren ustetan, familia da banakoaren garapena zehazten duen sistemarik sendoena. Gainera, ikusi izan da hainbat nahaste psikologiko zuzenki erlazionatuta daudela testuinguru familiarrean suertatzen diren harremanen kalitatearekin (Emerson eta Bögels, 2017). Zehazki, nahaste honetan haurra garatzen den familia- eta eskola-mikrosistemak nahaste honen bilakaeran zein garapenean eragin handiena duten faktoreak dira. Bi horien artean familiaren eragina nabarmentzekoa da; izan ere, bertan sortzen diren elkarrekintzak barneratuak izaten dira, duten esanguratsutasun afektiboa eta gertutasuna dela-eta (Santurde eta Del Barrio, 2016). Hortaz, esan daiteke familia-mikrosistemek nolabait nahaste psikologikoen norabidea baldintzatzen dutela.

Beraz, AGHNa duen haurraren gertuko testuingurua osatzen duten pertsonek gaitz honen arazoen gaineko kontzientzia baldin badute eta arazo horiei aurre egiteko beharrezko gaitasunak baldin badituzte, errazagoa izango da nahasteak garapen positiboa izatea. Aldiz, kideek haurraren beharrei erantzuteko gaitasuna izan ezean, AGHNaren sintomak areagotuko lirateke. Esku-hartze gehienetan soilik eskola-testuingurua hartzen da kontuan, eta azpimarratu beharra dago testuinguru familiarraren garrantzia, azkenengo horiek parte hartuz gero, emaitza askoz ere positiboagoak lortzen baitira (Ríos-Floréz eta López-Gutiérrez, 2018).

\subsection{Gurasoen heziketa-estiloak}

Gurasoak familia-mikrosistemaren osagai garrantzitsuenetarikoak dira. Eragin handia izan dezakete nahastearen bilakaeran eta, zehazki, gurasoen heziketaestiloak erabakigarri suerta daitezke. Heziketa-estilo ezegokiak (permisiboa, autoritarioa eta axolagabea) darabiltzaten kasuetan gaitz honen sintomatologia areagotzen dela aurkitu da; aldiz, heziketa-estilo eraginkorrak (demokratikoa) erabiltzeak umeek autorregulaziorako gaitasunak garatzea ahalbidetzen du (Fleck et al., 2015; Muñoz et al., 2017). Alegia, gurasoen heziketa-estiloek haurraren garapen sozioafektiboan zein haren nortasunaren alderdi askotan eragin zuzena dute. Gaur egun, lau heziketa-estilo bereizten ditugu (ikus 2. taula). 
2. taula. Gurasoen lau heziketa-estiloak eta ondorioak haurraren garapen psikologikoan.

\begin{tabular}{|l|l|l|l|}
\cline { 2 - 4 } \multicolumn{1}{c|}{} & \multicolumn{1}{c|}{$\begin{array}{c}\text { Afektu-maila } \\
\text { (komunikazioa) }\end{array}$} & $\begin{array}{c}\text { Kontrol-maila } \\
\text { (arauak) }\end{array}$ & \multicolumn{1}{c|}{$\begin{array}{c}\text { Ondorioak haurraren } \\
\text { garapen psikologikoan }\end{array}$} \\
\hline Permisiboa & Gehiegizkoa & Eskasa & $\begin{array}{l}\text { Autoestimu altua. } \\
\text { Gizarte-trebetasun eskasak. } \\
\text { Bulkadak kontrolatzeko } \\
\text { zailtasuna. } \\
\text { Eraginerrazak. }\end{array}$ \\
\hline Autoritarioa & Eskasa & Gehiegizkoa & $\begin{array}{l}\text { Autoestimu baxua. } \\
\text { Gizarte-trebetasun eskasak. } \\
\text { Erasokorrak eta oldarkorrak }\end{array}$ \\
& & izateko aukera. \\
\hline Axolagabea & Gabezia & Gabezia & $\begin{array}{l}\text { Autoestimu baxua. } \\
\text { Gizarte-gaitasun eskasak. } \\
\text { Bulkadak kontrolatzeko } \\
\text { zailtasuna. } \\
\text { Zailtasunak arauak betetzeko. }\end{array}$ \\
\hline & Egokia & Egokia & $\begin{array}{l}\text { Autoestimu altua. } \\
\text { Gizarte-gaitasun egokiak. } \\
\text { Norbere burua kontrolatzeko } \\
\text { gai. } \\
\text { Haurren autonomia egokia. }\end{array}$ \\
\hline
\end{tabular}

AGHNaren sintomatologiak, besteak beste, erruduntasuna, autoestimu baxua eta atsekabea sentimenduak eragin ditzake gurasoengan. Gainera, AGHNrik ez duten haurren gurasoekin alderatuta, ohikoa da beren burua ezgai ikustea guraso bezala (Santurde eta Del Barrio, 2013). Haur horien ezaugarriek eta gurasoek egoera horren aurrean jasaten duten estresak guztiz mugatu ditzakete guraso horien heziketa-estiloak. Izan ere, gurasoek egoera horretan jasaten duten hersturamailek afektua erregulatzeko gaitasuna murrizten dute eta nolabait umearen egoera psikologikoa baldintzatzen dutela ikusi izan da (Muñoz et al., 2017).

Aipatu bezala, heziketa mota desegokiek (permisiboa, autoritarioa edo axolagabea) eragin negatiboa dute AGHNan, baina heziketa mota bakoitzak ez du eragin berbera. Zehazki, ikusi da estilo autoritarioek edo jarrera agresiboek modu nabarmenago batean indartzen dutela gaitz honen ebaluazio negatiboa (ColomerDiago, Berenguer-Forner, Tárraga-Mínguez eta Miranda-Casas, 2014).

Gutxi dira nahaste honen azpimotak kontuan hartzen dituzten ikerketak, horien artean Tzang, Chang eta Liu autoreek (2009) egindakoa, bertan azpimota konbinatua diagnostikatua zutenen gurasoek tentsio-maila handiagoa zutela ikusi 
zen, arreta-gabezia soilik zuten umeen gurasoek baino. Hori gerta daiteke batetik, azpimota horren sintomak nolabait larriagoak direlako, edota gurasoek, heziketari dagokionez, ez dutelako beren burua gai ikusten eta horrela haien heziketa-estiloen kalitatea kaltetua ateratzen da (Santurde eta Del Barrio, 2016).

Finzi, Manor eta Tayanok (2006) egindako ikerketan batean, kontrol-maila altuagoak ikusi izan ziren talde hiperaktiboko gurasoen artean, arreta-gabezia zuten umeen gurasoen artean baino. Jarrera oldarkorren aurrean gurasoek jarrera desegoki horiek zigortuz gero edo horiekiko jarrera ez-tolerante bat aurkeztuz gero, hiperaktibitatearen sintomatologia mantendu edo areagotzea eragiten zuten. Bestalde, horrekiko tolerantzia eta laguntza eskaintzen zuten gurasoek umeengan sintomatologia hau arintzeko ezinbestekoak diren gaitasun autorregulatzaileen agerpena eragiten zuten (Raya, Herreruzo eta Pino, 2008).

Orain arte esan bezala, gurasoen heziketa-jarrera desberdinek sintomatologia zehatz baten agerpena erraztu dezakete, baina amaren edo aitaren eragina izateak ere inpaktu desberdina izan dezake. Nahiz eta ikerketa gehienek amaren jarrera soilik aztertu, amak umearenganako duen begirune-faltak eta sentikortasun-maila baxuek (estilo axolagabea) arreta-gabezia neurri batean aurresaten dutela ikusi da eta, bestetik, aitaren jarrera intrusiboek (estilo autoritarioa) umearen hiperaktibitatea edo inpultsibitatea eragin dezakeela ikusi izan da ere (Keown, 2012).

Gurasoen eta AGHNa duten seme-alaben arteko interakzioei dagokienez, azterketa sakon bat egin ondoren, ikusi da guraso horiek mintzaira zakarragoa eta jarrera zurrunagoak erabiltzen dituztela, umeen jokabideen aurrean komentario negatiboak izan ohi dituztela eta gainera beren haurrei muga edo neurri murriztaileak ezartzen dizkietela. Gainera, jokaera hauek guztiek inolako azalpenik eman gabe izaten dituzte (Goldstein, Harvey eta Friedman-Weieneth, 2007; Polanco-Barreto, Arboleda-Bustos, Pinto, Ávila eta Vásquez, 2016). Amak soilik kontuan hartzen zituen beste ikerketa batean, horiek kritikak eta gutxiespenak maizago aurkezten zituztela, adierazpen afektibo, onarpen eta komunikazio-maila baxuagoak eta, azkenik, umeekiko babes- eta konfiantza-jarrera murritzagoak ikusi izan ziren (Rubiales, Bakker, Russo eta Rubiales, 2014).

\subsection{Atxikimendua}

Gurasoen heziketa motek ez ezik, gurasoekiko jaiotzetik sortzen ditugun lotura afektiboen nolakotasunek edo, bestela esanda, haurrek garatzen duten atxikimendu motak ere AGHNan eragina dutela baieztatu izan da. Zehazki atxikimendu mota ezziurra gaitz honekin erlazionatuta ikusi izan da hainbat ikerketatan (Santurde eta Del Barrio, 2013; Storebø, Rasmussen eta Simonsen, 2016).

Bowlbyk (1972) planteatutako atxikimenduaren teoriaren arabera gizakien osasun psikologikoa estuki erlazionatuta dago testuinguru familiarrean bizitako lehenengo esperientziekin. Horrela, haurra-ama artean sortutako lotura horri esker haurrak biziraupenerako beharrezkoak dituen babes fisikoa eta euskarri emozionalak lortuko ditu. Lotura emozional berezi hori denboran zehar mantenduko da. Elkarrekintza 
horren kalitateak nortasunaren osaketa baldintzatuko du, bertan haurrak bere irudikapen sozialak, besteenak eta norberarenak eraikiko ditu. Beraz, esandakoa kontuan harturik esan daiteke atxikimendua banakoaren eta haren zaintzaile-irudia betetzen duen pertsona edo pertsonen arteko interakzioaren ondorioz sortzen dela. Hortaz, landu daitekeen zerbait da, betiere bi alderdiak kontuan hartuz (Jauregizar, 2012).

\section{Atxikimendu motak}

Esan bezala, haurrek beren atxikimendu-irudia segurtasun-oinarritzat hartzen dute, horrela zaintzaileen gertutasuna bilatzearen eta testuinguruaren esplorazioaren arteko oreka bat gertatuko da. Ainsworth-en taldeak (1979) aipatutako haurren bi jokabide horiek kontuan harturik hiru atxikimendu mota bereizi zituen: atxikimendu ziurra, ez-ziurra eta desantolatua.

\section{Atxikimendu ziurra}

Atxikimendu mota hau barneratu duten haurrek beren atxikimendu-irudia segurtasun-oinarri bezala ikusten dute. Bertan esan daiteke atxikimendu-irudia (edo zaintzailea) haurraren behar biologikoak nahiz emozionalak asetzeko gai dela, eta ondorioz bien arteko harreman sendo bat garatzen da, non berotasuna, konfiantza eta segurtasuna nabariak diren.

Atxikimendu mota hau garatu ahal izateko garrantzitsuena ez da zaintza bera edo zaintza horretan ematen dugun denbora, baizik eta harreman horren kalitatea: maitabera, gertukoa eta jarraitua, zaintzailea eta haurra gustura sentiarazten dituena. Zaintzaileak eta haurrak elkarrekin egoteagatik pozik egon behar dute. Bowlbyk (1972) dioen bezala, haurrak sentitu behar du ama beraz harro dagoela eta gustura dagoela berarekin dagoenean.

\section{Atxikimendu ez-ziurra}

Talde honen barnean, bi atxikimendu mota ditugu, batetik anbibalentea eta bestetik saiheskorra. Haur anbibalenteei dagokienez, larritasun handia adierazten dute, haur hauek erreakzio anbibalenteak erakusten dituzte: alde batetik, hurbiltasuna eta kontaktua bilatzen saiatzen dira, baina beste alde batetik, amaren aurka azaltzen dira kontaktua errefusatuz. Haserrea eta kezka edo urduritasuna nabariak dira. Bertan, zaintzaileari oso zaila egingo zaio atxikimendu anbibalentea duen haurra kontsolatzea. Amak jarrera desberdinak txandakatuko ditu; batzuetan haurraren beharrak aseko ditu, eta, beste batzuetan, ez ditu kontuan hartuko.

Bestetik, atxikimendu saiheskorra dugu. Haur horiek larritasun-maila oso baxua erakusten dute, baina horrek ez du esan nahi larritasunik sentitzen ez dutenik. Kanpotik ikusten dena zera da: haur lasaiak direla, emozionalki kontrolatuak eta atxikimendu-irudiaren kontaktua saihesten dutela. Baina probatu da, hori soilik itxurakeria dela; izan ere, azterketa fisiologikoetan larritasun-mailak aurkitu izan dira. Mota honetan esan daiteke atxikimendu-irudiak ez duela sentsibilitaterik erakusten haurraren sentimenduekiko eta haurrarekiko kontaktua saihesten duela. Haurraren tristuraren aurrean beste alde batera begiratzen du, eta, hala, haurra 
bere egoera emozionala aldatzera eta ezkutatzera behartzen du. Zaintzaile horiek sarritan erabiltzen dituzte zigorra eta mehatxua.

\section{Atxikimendu desantolatua}

Mota hau atxikimendu anbibalentearen eta saiheskorraren arteko konbinaziotzat jo daiteke. Haur hauek portaera desantolatuak erakusten dituzte, kontaktua eskatuz baina gero hori errefusatuz. Ikerketen arabera, mota honetako haurrek utzikeria edo tratu txarrak bizi izan dituzte.

\subsubsection{Atxikimendua eta $A G H N a$}

Hainbat ikerlanek atxikimenduaren eta AGHNaren arteko erlazioa aztertu izan nahi dute. Esaterako, Fleck eta haren kolaboratzaileek (2015) egindako ikerketa batean, amaren atxikimendu ez-ziurraren eta haur txikien hiperaktibitatearen arteko lotura aurkitu zuten, gainera, ikusi zuten lotura hori askoz ere sendoagoa bihurtzen zela aitaren depresioarekin konbinatua aurkezten zen kasuetan. Aiten atxikimenduari dagokionez, ez zuten loturarik aurkitu. Kissgen eta kideek (2009) haurren AGHNaren sintomen larritasunarekin batera, amak atxikimendu ez-ziurra izateko probabilitatea ere igotzen zela ikusi zuten. Bestetik, Finzi eta kideek (2006) heziketaestiloen eta atxikimenduaren arteko erlazioa aztertu zuten. Bertan, gehiegizko autonomia sustatzen zuten heziketa-estiloak gaitz honen sintomekin erlazionatzen zirela ikusi zuten, eta bestetik, gehiegizko kitzikapen emozionalaren atxikimendu anbibalentearekin lotura aurkitu zuten. Gainera, autonomia-murriztapena gehiegizko jarduerarekin aurkezten zenean hura atxikimendu saiheskorrarekin erlazionatua zegoela ikusi zuten. Bestetik, Guttman-Steinmetz eta Crowellek (2006) emaitza berberak ikusi zituzten atxikimendu ez-ziurrari dagokionez.

Adibidez, 384 haurrekin Keskin eta Çam (2010) autoreek egindako ikerketa batean hiperaktibitatea eta arreta-gabeziaren sintomen eta atxikimendu ez-ziurraren arteko lotura ikusi zuten. Abrines eta kideek (2012), aldiz, haurren atxikimendu ziurraren eta arreta-gabezia izateko probabilitate baxua izatearen arteko lotura aurkitu zuten. Beste ikerketa batean Niederhoferrek (2009) aurkitu zuen atxikimendu ez-ziurra zuten 69 haurren artean 62k AGHNaren sintomak aurkezten zituztela; aldiz, 22 haurrez osatutako kontrol-taldean soilik 5ek aurkezten zituzten sintoma horiek. Beranduago, Thorell eta kideek (2012) emaitza berdintsuak aurkitu izan zituzten 6-8 urte-bitarteko haurren artean. Atxikimendu goiztiar desantolatuaren kasuan, haurrengan arreta-gabezia eta jarrera kanporatzaileen agerpena aurresaten duela aurkitu izan da ere hainbat ikerketatan (Bohlin, Eninger, Brocki eta Thorell, 2012).

\section{AGHNa eta esku-hartzea familia-sisteman}

AGHNan erabilitako tratamendu anitzen artean, sintomatologia gutxitzeko eraginkortasun handiena erakutsi dutenak gurasoak barne hartzen dituzten horiek direla probatu izan da, terapia konduktualarekin eta gaitasun sozialen entrenamenduarekin batera (Serrano-Troncoso, Guidi eta Alda-Díez, 2013). Geroz eta maizago aipatzen da gurasoen parte-hartze aktiboaren garrantzia; izan ere, bertan jaramon egitea edota harkor izatea soilik ez da nahikoa. Esan bezala, 
gurasoek ekimenetan jarrera aktiboa izan behar dute, terapiaren parte eta jasotzaile izan behar dute. Ikuspegi sistemiko hau oso garrantzitsua da emaitza positiboak lortu ahal izateko (Piotrowska et al., 2017).

Ekimen hauek «Hazkuntzan esku-hartzea» edo «Gurasoen ahalduntzea» izenak hartzen dituzte eta ikaskuntza sozialean nahiz jokaeren ikaskuntzan oinarrituak daude (Eyberg, Nelson eta Boggs, 2008). Programa horietan gurasoei heziketan funtsezkoak diren gaitasunak irakasten zaizkie eta aldi berean umeekiko duten konpromiso positiboa sustatu, jokaera positiboak bultzatu eta errefortzatu eta haurren jokaera ezegokien aurrean dituzten erantzun emozionalak murriztea lortzen da ere (Piotrowska et al., 2017).

Ikuspegi sistemikoa barne hartzen duten programek jarduera ezberdin anitz barne hartzen dituzte, hala nola rolen jokoak, eztabaidak, zuzeneko edo film bitarteko erakustaldiak eta terapia barneko nahiz kanpoko estrategien praktikak (Barlow, Smailagic, Huband, Roloff eta Bennett, 2012). Orokorrean programa hauen iraupena 8-14 saiokoa izaten da, astero 1-2 orduko saio bat izanik. Ikerketek probatu izan dute programa hauen emaitza positiboek esku-hartzetik 8-10 urte pasa arte irauten dutela. Gurasoentzat ere emaitza positiboak dakartzate hainbat alderdi psikosozialetan, osasun mentalean eta bikotearekiko harremanaren gogobetetzean ere. Azkenik, errentagarri direlako ebidentzia ere badago (Sanders, Kirby, Tellegen eta Day, 2014).

Serrano eta haren ikerkideen (2013) arabera, AGHNdun haurren sintomatologia gutxitzeko, gurasoekiko atxikimendu ziurra bultzatzeko eta hezitzaileen heziketaestiloak demokratizatzeko eraginkorrenak izan diren hiru programak hauexek dira: Programa de Paternidad Positiva // Gurasotasun Positiboaren Programa (Triple P), The New Forest Parenting Programme // Gurasotasun eredu berrien programa (NFPP) eta Incredible Years parent Training Programme // Urte zoragarriak deritzon gurasoentzako entrenamendu programa (IY). Jarraian, laburki aztertuko dira.

\subsection{Familiakideei (indibidualki) zuzendutako programa}

\section{Programa de Paternidad Positiva (Triple $P$ )}

Programa honen helburua da gurasoak nahasteaz funtsezkoa den informazio eta estrategiez hornitzea. AGHNa duten 6-12 urte-bitarteko gurasoengana bideratuta dago. Guztira 10 saioko iraupena duen programa honetan, estrategia konduktualez gain, jarrera desegokiak identifikatzeko eta kontrolatzeko teknikak irakasten dira. Gurasoak AGHNa ez duten haurrekin erabiltzen diren teknika berberak erabili behar dituztela kontzientziatzen dira. Jarrera egokiak errefortzu positiboaren bitartez bultzatu eta negatiboak zigorraren bitartez diskriminatzera irakasten die ere. Bestetik, gurasoen arrisku-faktoreak identifikatzeko ere balio du, hala nola depresioa, sostengu-falta, estresa, gainkarga emozionala, etab. Orokorrean, gurasoei berrezarpen kognitiboa, estresaren maneiua, komunikazio-gaitasunak eta aurre-egite estrategiak irakasten zaizkie. 
Berriki probatu izan da programa honen eraginkortasuna; izan ere, Garreta, Beltrán eta Barceló autoreek (2018) ospitaleko testuinguruan Triple P-aren eragina aztertu izan zuten. Bertan, AGHNa zuten 21 haurren gurasoek parte hartu zuten. Programaren ondoren, haurrengan sintomen hobekuntza nabarmena ikusi zen eta gainera guraso horien heziketa-estiloen hobekuntza ere agertu zen. Bor, Sanders eta Markie-Dadds (2002) autoreek ere, AGHNaren tratamenduan programa honen eraginkortasuna aztertu izan zuten. Bertan hainbat familia programaren jasotzaile izan ziren. Emaitzetan erakutsi zuten gaitzaren sintomatologia esanguratsuki hobetu zela eta gainera gurasoen heziketa-disfuntzioen murriztea lortu zela.

\subsection{Familia-sistema osoari (elkarrekin) zuzendutako programak}

\section{The New Forest Parenting Programme (NFPP)}

Programa honen helburua gurasoak estrategia eta teknika eraginkorretan heztean datza ere. Kasu honetan, 3-12 urte dituzten haur eta gurasoentzat prestatua dago eta 8 asteko iraupena du. Programa honek berezitasun bat du, haurraren testuinguru naturalean aplikatzen dela, etxean, hain zuzen ere. Jarrera-aldaketan oinarritzen da eta jokoaz baliatzen da ezagutza transmititzeko eta funtzio exekutiboak, arreta eta memoria bezalako funtzioak lantzeko.

Sonuga-Barke, Thompson, Daley eta Laver-Bradbury autoreek 2004. urtean programa hau aplikatu zuten AGHNrako tratamenduaren parte. Emaitzak aztertu ondoren, nahastearen sintomen murrizketa eta amaren ongizatearen areagotzea lortu zela ikusi zuten. Gainera eragin horrek tratamendutik 15 astera iraun zuen eta arreta-gabezia zein hiperaktibitate-mailak \% 53 jaitsi ziren. Geroago, Thompson eta laguntzaileek (2009) botika estimulatzaileekin lortutako emaitzekin konparagarri ziren emaitzak lortu zituzten; izan ere, AGHNaren sintomen murrizketa esanguratsua lortu izan zen.

\section{Incredible Years parent Training Programme (IY)}

Hirugarren programa honetan esku-hartzea taldeka egiten da eta adinaren araberako 4 tarterentzat prestatua dago: 6 aste - urte 1; 1-2 urte; 3-5 urte eta 6-12 urte. Aurreko bi taldeetan ( 6 aste - 3 urte) haurrek eta haien gurasoek elkarrekin parte hartzen dute, non 2 ordu eta erdiko 12 sesio dauden. Bertan, jokoaren bitartez haurrekiko harreman positiboa bultzatzeaz gain, goraipamenen eta sarien erabilpena, mugen ezarpen eraginkorra eta desobedientziaren aurreko maneiua irakasten da. Horrela nolabait gurasoen eta haurren arteko atxikimendu osasuntsua bultzatu eta etorkizunera begira AGHNaren sintomen agerpena prebenitu daiteke. Programa honek haurren arreta-gabezia eta hiperaktibitate/inpultsibitatearen sintomak \% 52 murrizten dituela probatu da (Siegenthaler et al., 2013).

Jones, Daley, Hutchings, Bywater eta Eames adituek 2009an programa hau indarrean jarri izan zuten AGHNa zuten haurren gurasoekin. Bertan talde esperimentalak sintomekiko hobekuntza esanguratsua lortu zuen kontrol-taldearekin alderatuta. Beranduago aurretik lortutako emaitzak berresten dituen (WebsterStratton, Reid eta Beauchaine, 2011) programa dugu, non jarrera-aldaketa 
positiboa, sintomatologiaren murriztapena, konpetentzia sozialen eta erregulazio emozionalaren hobekuntza jaso zen. Emaitza horiek programaren inplementaziotik urtera aztertuak izan ziren berriz eta emaitza berberak jaso izan ziren.

\section{AGHNa duten haurren gurasoei orientabideak}

Lan osoan zehar sarri aipatu den bezala, gurasoak nahaste honen garapenean elementu erabakigarria dira. Izan ere, ikusi den moduan, haien jarrerak eta jokaerak gaitzaren norabidea alda dezakete. Guraso asko egoera horren aurrean galduta ikusten dira, egoerari aurre nola egin jakin gabe. Gurasoak haurren eredu direnez, haiek ere era egokian jokatu beharko dute arlo guztietan haurrek beharrezko estrategiak berreskura ditzaten.

Honenbestez, Euskal Autonomia Erkidegoan EUSARGHIk (Euskadiko Arreta Gabezia eta Hiperaktibitatearen Federakuntza: https://www.eusarghi.org/eu/) barne hartzen dituen hiru elkarteetara jo dezakete gurasoek: ADAHIgi (Gipuzkoako Arreta Gabezia eta Hiperaktibitatearen Elkartea: https://www.adahigi.org/eu/), ANADAHI (Arabako Arreta Gabezia eta Hiperaktibitatea duten Haur eta Helduen Elkartea: https://www.anadahi.org/eu/hasiera-2/) eta AHIDA (Bizkaian Arreta Gabezia eta Hiperaktibitatea duten Haurren Gurasoen Elkartea: http://tdahbizkaia.blogspot. com/). Hiru elkarteetako webguneetatik eratorritako proposamenak lau arlotan sailkatzen dira: emozionala, kognitiboa, konduktuala eta soziala.

\subsection{Orientabideak arlo emozionalean}

- Garrantzitsua da konfiantzazko klima ezartzea etxean, horrela haien beharrak asetzeko eskakizunak egin ahalko dituzte.

- Heziketa-estilo demokratikoan eta atxikimendu ziurrean oinarritutako harremanak sustatu. Adinari egokitutako kontrol eta afektua orekatuz, haurraren beharrekiko sentikortasuna azalduz eta baldintzarik gabeko onarpenean oinarrituz.

- Haur hauen autoestimua orokorrean baxuagoa izaten da, eta hura mezu positiboekin eta afektuzko ekintzekin indartzea oso garrantzitsua da. Gurasoen kasuan ere landu beharreko alderdi bat izan daiteke; izan ere, beren burua ezgai ikusten dute heziketa-garaian.

- Ezinbestekoa da haurraren gaitasunak nabarmentzea eta haren Iorpen guztiak, nahiz eta hauek txikiak izan, txalotzea.

- Gurasoak gertu eta eskuragarri mantendu, haurrek segurtasun-iruditzat har ditzaten.

- Enpatiaz jokatu, haurren lekuan jarriz momentu oro eta jakinaraziz kontziente zarela bere egoeraz.

- Komunikazio asertiboa ezinbestekoa da.

- Ondoeza edo bestelako emozio negatiboak onartu. Emozio guztiak beharrezkoak baitira. 
- Arreta pentsamendu negatiboetatik desbideratu, orokorrean gehiegi fokalizatzen baikara horietan eta horrek frustrazio- eta antsietate-emozioak sorrarazten ditu.

- Norberaren zein besteen emozioen ezagutza, horien ulermen eta onarpena sustatu; baita emozio desatseginen erregulazioa ere.

- Egunero aisialdirako tartetxo bat gorde familia osoak elkarrekin une atsegin bat pasatzeko.

\subsection{Orientabideak arlo kognitiboan}

- Zereginak pauso txikiagotan banatu, horien jarraipena errazagoa izan dadin.

- Informazioa era egokian laburbiltzen duten mapa kontzeptualak erabili.

- Eskolako lanak egiteko toki lasai eta egoki bat izatea ezinbestekoa da, distraktoreetatik urrun (horrek ez du esan nahi umea erabat isolatu behar denik).

- Oso erabilgarria izan daiteke agenda bat erabiltzea, bertan haien eginbehar akademiko guztiak zehazteko. Informazio-iturri gisa baliagarria izan daiteke eta gainera egunean zehar azaldu diren zailtasunak edota aurrerapenak barneratu ditzakete gurasoek.

- Barne-motibazioa eta arreta lortzeko, haien interesekoak diren gaiak zeintzuk diren galdetu.

- Funtzio exekutiboak lantzea bereziki komenigarria da. Bertan jokoak oso erabilgarriak izan daitezke: inhibizioaren kontrol-jokoak (adib. "go/ no go» jokoak), planifikazio-jarduerak (adib. dorreen jokoak), malgutasun kognitibozko jokoak (adib. switching zereginak), eraikitze-zereginak, aldez aurretiko planifikazio- eta ebazpen-jokoak (adib. hiru lerrokoa).

- Sormena lantzea garrantzitsua izango da haurraren irudi positiboa sustatzeko. Hala nola eskulanen bidez, rolen interpretazioa, hezkuntza fisikoa, artea (dantza, pintura, antzerkia).

- Haur hauek bereziki sortzaileak dira, beraz, ipuinak kontatzerakoan, eta haien arreta erakarriko bada, kitzikapen gehiago erabili behar da: kolore, forma, testura eta proportzio askotariko kinadak.

- AGHNa duten haurren estilora egokituko diren ikaskuntza-esperientziak diseinatu (etxean zein eskolan). Horretarako, Gardnerren (1993) adimen anizkoitzen lerroan koka gaitezke: hitzezko adimena, zenbakizkoa, espaziala, musikala, gorputz-adimena, pertsonen artekoa, pertsona barnekoa eta ekologikoa.

\subsection{Orientabideak arlo konduktualean}

- Haurrari argi zehaztu behar zaio hasieratik zer espero den beragandik, jokaera egokiek bere buruari ekarriko dizkioten onurak ondo azalduz eta mugak ezarriz ere. 
- Ekintza positiboen ondorengo indartzaileen zerrenda egitea komenigarria litzake. Horiek, haurren lehentasun eta ezaugarriekin bat etorri beharko dute, errefortzua eraginkorra izan dadin. Gogoratu behar da, errefortzu hauek ez dutela zertan materialak izan.

- Errefortzu hauek gutxika desagertzen joan beharko dira, haurra ohitu ez dadin. Esfortzua ere kontuan hartu behar da, ez soilik lorpenak.

- Jokaera eta pertsona ezberdindu behar dira.

- Gogoratu gurasoak edota familiako kideeak haurren eredu direla, beraz, kide denek haien portaera modulatu beharko dute, hura eredugarri izan dadin.

- Oso garrantzitsua da errutina bat ezartzea eta iraunkorra izatea.

- Haurra haren mugak gainditzera bultzatu, betiere bere buruaren irudi positibo bat sustatuz.

- Asaldura handia sortzen duten ekintzen ondoren, erlaxazioan denboraldi txiki bat jardun.

- Ordenagailuetako programak ere erabil litezke, bat-bateko atzeraelikadura, kinaden autokontrola eta elkarreragin interesgarria sustatzeko.

\subsection{Orientabideak arlo sozialean}

- Haurren alderdi soziala bultzatzea ezinbestekoa da. Bai lagunen arteko harremanekin, baita familiarteko harremanekin ere.

- Etxeko giro lasaia eta konfiantzazkoa sortu, bizikidetzan oinarritutakoa. Bertan komunikazioa egokia izan dadin eta haurrek behar duten heinean laguntza eska dezaten.

- Ez errieta egin edo kritikatu besteen aurrean zerbait desegokia egin ostean. Lasaitasunez hartu eta, ondoren, esan beharrekoa esan modu asertibo eta konstruktibo batean.

- Lagunekin harremanak izateko modua behatu eta hura hobetzeko (beharrezkoa bada) iradokizunak eman.

\section{Ondorioak}

Jakin badakigu, Arreta Gabezia eta Hiperaktibitatea Nahastean hainbat faktorek dutela eragina, horien artean familia-sistema izan da lan honen ardatz nagusia. Testuinguru horretan, errebisio bibliografiko honetan bildutako ikerlanen emaitzek bi alderdi nabarmentzen dituzte: atxikimendu ziurra eta heziketa-estilo demokratikoa. Hori horrela izanik ere, bi alderdi horiek kontuan hartzen dituzten esku-hartze edo tratamenduak oso urriak direla ikusi da. Bestela esanda, arazoaren oinarria eta iturburua gaitza pairatzen duen haurraren gain kokatzen da, berari tratamenduaren ardura esleituz. 
Aipatutako bi alderdi horiek (atxikimendua eta heziketa-estiloa) kontuan hartzen dituzten ikerketetan hainbat puntu hobetzeko aurkitu dira ere, etorkizunerako ikerketaildo gisa. Batetik, gurasoen heziketaren garrantziaz aritzen diren azterlan askok ama soilik hartzen dute hezitzaile, aita edo guraso-papera betetzen duten gainontzeko pertsonak kanpoan utziz. Esan beharra dago ere, programa gehienetan nahiz eta gurasoak kontuan hartzen direla jakinarazi, saioetan ez dagoela elkarrekintzarik haur eta gurasoen artean. Gainera, alderdi emozionala ez da asko kontuan hartzen, bai, ordea, pauta kognitibo eta konduktualak. Bukatzeko esan, literaturan argitalpen gutxi dagoela esku-hartze programa hauen emaitzekin, are gutxiago, ebaluaziosistemaren diseinuan kontrol-taldea barne hartzen dutenak.

Hutsune hauek ikusita, lan honen bukaeran ikuspegi sistemikoan oinarritutako eta gurasoei bideratutako hainbat pauta proposatu dira. Hauek haurraren testuinguru naturalean aplikatzeko asmoz. Aholku horiek alderdi emozionala barne hartu dute; izan ere, heziketa-estilo egokietan eta atxikimendu ziurrean oinarriturik daude. Horrela, jarraibide labur horiekin, nahastea duten haurren nahiz sistema osoaren garapen osasuntsu bat susta liteke.

Etorkizunari begira, ikerketa gehiagoren beharra ikusten da esku-hartze sistemikoen eraginkortasunari buruzko informazio gehiago lortzeko. Bestetik, eskuhartze edo programa hauetan aiten edo gainontzeko zaintzaileen parte-hartzea sustatzea ere garrantzitsua litzateke. AGHNaren azpimotei dagokienez, funtsezkoa litzateke horien berezitasunak kontuan hartu eta mota bakoitzari egokitutako eskuhartze espezifikoago bat bultzatzea.

Laburbilduz, lan honetan zehar AGHNaren etiologian, ebaluazioan eta, batez ere, esku-hartzean ikuspegi sistemikoaren garrantzia azpimarratu nahi izan da, eta, horrekin batera, haurraren eta familiakideen alderdi emozionala elkarlanean sustatzearen garrantzia bultzatu da: «Familia eta hiperaktibitatea elkarrekin biziz».

\section{Erreferentzia bibliografikoak}

Abrines, N.; Barcons, N.; Marre, D.; Brun, C.; Fornieles, A. eta Fumad, V. (2012): «ADHD-like symptoms and attachment in internationally adopted children», Attachment and Human Development, 14(4), 405-423.

Ainsworth, M.S. (1979): «Infant-mother attachment», American Psychologist, 34(10), 932937.

APA, American Psychiatric Association (2014): Guía de consulta de los criterios diagnósticos del DSM5, American Psychiatric Publishing, Washington, DC.

Barkley, R.A. (1990): Attention deficit hyperactivity disorder: A handbook of diagnostic and treatment, Guilford Press, New York.

Barlow, J.; Smailagic, N.; Huband, N.; Roloff, V. eta Bennett, C. (2012): «Group-based parent training programmes for improving parental psychosocial health", Cochrane Database of Systematic Reviews, 5, 1-175.

Bohlin, G.; Eninger, L.; Brocki, K. C. eta Thorell, L.B. (2012): «Disorganized Attachment and Inhibitory Capacity: Predicting Externalizing Problem Behaviors», Journal of Abnormal Child Psychology, 40(3), 449-458. 
Bor, W.; Sanders, M.R. eta Markie-Dadds, C. (2002): «The Effects of the Triple Positive ParentingProgram on Preschool Children With Co-Occurring Disruptive Behavior andAttentional/Hiperactivity Dificulties», Journal of Abnormal Child Psychology, 30(6), 571-587.

Bowlby, J. (1972): Cuidado maternal y amor, Fondo de Cultura Económica, Mexiko.

Brickenkamp, R. (2002): D2, Test de atención, TEA Ediciones, Madril.

Bronfenbrenner, U. (1987): La ecología del desarrollo humano, Paidós, Bartzelona.

Canals, J.; Morales-Hidalgo, P.; Jané, M. C. eta Domènech, E. (2018): «ADHD prevalence in Spanish preschoolers: comorbidity, socio-demographic factors, and functional consequences", Journal of Attention Disorders, 22(2), 143-153.

Colomer-Diago, C.; Berenguer-Forner, C.; Tárraga-Mínguez, R. eta Miranda-Casas, A. (2014): «Estilos de disciplina y trastornos comórbidos de adolescentes con trastorno por déficit de atención/hiperactividad. Un estudio longitudinal», Revista de Neurología, 58, 31-36.

Conners, C.K. (1989): Manual for Conners' Rating Scales, Multi-Health Systems Inc., Toronto, Kanada.

(1994): The Continuous Performance Test (CPT): Use as a diagnostic tool and measure of treatment outcome, APA: American Psychological Association, Washington, DC.

Cornejo, E.; Fajardo, B.F.; López, V.M.; Soto, J. eta Ceja, H. (2015): «Prevalencia del déficit de atención e hiperactividad en escolares de la zona noreste de Jalisco», Revista Médica MD, 6(3), 190-195.

Emerson, L.M. eta Bögels, S. (2017): «A systemic approach to pediatric chronic health conditions: why we need to address parental stress», Journal of Child and Family Studies, 26(9), 2.347-2.348.

Eyberg, S.M.; Nelson, M.M. eta Boggs, S.R. (2008): «Evidence-based psychosocial treatments for children and adolescents with disruptive behavior», Journal of Clinical Child and Adolescent Psychology, 37(1), 215-237.

Farré, A. eta Narbona, J. (2001): EDAH. Escalas para la evaluación del trastorno por déficit de atención con hiperactividad, TEA ediciones, Madril.

Finzi, R.; Manor, I. eta Tyano, S. (2006): «ADHD, Temperament and Parental Style as Predictors of the Child's Attachment Patterns», Child Psychiatry Human Development, 37(2), 103-114.

Fleck, K.; Jacob, C.; Philipsen, A.; Matthies, S.; Graf, E.; Hennighausen, K.; ... eta Retz, W. (2015): «Child impact on family functioning: a multivariate analysis in multiplex families with children and mothers both affected by attention-deficit/hyperactivity disorder (ADHD)», ADHD Attention Deficit and Hyperactivity Disorders, 7(3), 211223.

García, E. eta Magaz, A. (2000): EACP. Escalas de áreas de Conducta-Problema. Manual de referencia, ALBOR-COHS, Bilbo.

García, E.; Magaz, A. eta Sandín, A. (2000): Escala Magallanes de Evaluación del Trastorno por Déficit de Atención con Hiperactividad (EMTDA-H), ALBOR-COHS, Bilbo.

Garreta, E.; Beltrán, T.J. eta Barceló, M.S. (2018): «Análisis de la efectividad de un programa de entrenamiento de padres de niños con TDAH en un ambiente hospitalario», Actas Españolas de Psiquiatría, 46(1), 21-28.

González, R.; Bakker, L. eta Rubiales, J. (2014): «Estrategias de afrontamiento y estilos parentales en madres de niños con y sin trastorno por déficit de atención e hiperactividad», Pensando Psicología, 10(17), 71-84.

González-Castro, P.; Rodríguez, C.; Cueli, M.; García, T. eta Álvarez, D. (2015): «Diferencias en ansiedad estado-rasgo y en atención selectiva en Trastorno por Déficit de 
Atención con Hiperactividad (TDAH)», International Journal of Clinical and Health Psychology, 15(2), 105-112.

Guttmann-Steinmetz, S. eta Crowell, J.A. (2006): «Attachment and externalizing disorders: A developmental psychopathology perspective», Journal of the American Academy of Child and Adolescent Psychiatry, 45(4), 440-451.

Haranburu, M.; Guerra, J.; Torres, E. eta Zumalabe, T. (2006): Arreta gabezia eta hiperaktibitatea, Hik Hasi, Donostia.

Herrera, B. eta De María, S. (2018): Trastorno por déficit de atención e hiperactividad como factor asociado a trastorno por abuso de sustancias psicoactivas, Doktoretza Tesia, Universidad Antenor Orrego.

Iriarte, Y.; Díaz-Orueta, U.; Cueto, E.; Irazustabarrena, P.; Banterla, F. eta Climent, G. (2016): «AULA - advanced virtual reality tool for the assessment of attention: Normative study in Spain», Journal of Attention Disorders, 20, 542-568.

Jauregizar, J. (2012): Atxikimendua ulertzen hezkuntzaren ikuspuntutik, Euskara eta Eleaniztasuneko errektoreordetzaren sare-argitalpena, Bilbo.

Jones, K.; Daley, D.; Hutchings, J.; Bywater, T. eta Eames, C. (2007): «Efficacy of the Incredible Years Basic parent training programme as an early intervention for children with conduct problems and ADHD», Child: Care, Health and Development, 33(6), 749756.

Jusyte, A.; Pfister, R.; Gehrer, N. eta Schönenberg, M. (2019): «Risky business! Behavioral bias and motivational salience of rule-violations in children with conduct disorder», Psychiatry Research, 271, 740-746.

Keown, L.J. (2012): «Predictors of boys' ADHD symptoms from early to middle childhood: The role of father-child and mother-child interactions", Journal of Abnormal Child Psychology, 40(4), 569-581.

Keskin, G. eta Cam, O. (2010): «Adolescents' strengths and difficulties: approach to attachment styles», Journal of Psychiatric and Mental Health Nursing, 17(5), 433-441.

Kissgen, R.; Krischer, M.; Kummetat, V.; Spiess, R.; Schleiffer, R. eta Sevecke, K. (2009): «Attachment representation in mothers of children with attention deficit hyperactivity disorder», Psychopathology, 42(3), 201-208.

Londoño, D. E. (2017): «El trastorno por déficit de atención con hiperactividad: una mirada socio-cultural», Revista de la Asociación Española de Neuropsiquiatría, 37(132), 477-496.

McAuley, T.; Crosbie, J.; Charach, A. eta Schachar, R. (2017): «Clinical, sociobiological, and cognitive predictors of ADHD persistence in children followed prospectively over time». Journal of Abnormal Child Psychology, 45(4), 765-776.

Muñoz, A.; Lago, R. eta Sánchez, M. (2017): «Family Impact and Parenting Styles in Families of Children with ADHD». Journal of Child and Family Studies, 26(10), 2.810-2.823.

Niederhofer, H. (2009): «Attachment as a component of attention-deficit hyperactivity disorder». Psychological Reports, 104(2), 645-648.

OMS (2018): ICD-11. International Classification of Diseases $11^{\text {th }}$ Revision. The global standard for diagnostic health information, WHO: World Health Organization.

Piotrowska, P.J.; Tully, L.A.; Lenroot, R.; Kimonis, E.; Hawes, D.; Moul, C.; ... eta Dadds, M.R. (2017): «Mothers, fathers, and parental systems: A conceptual model of parental engagement in programmes for child mental health-Connect, Attend, Participate, Enact (CAPE)», Clinical Child and Family Psychology Review, 20(2), 146-161.

Polanco-Barreto, A.M.; Arboleda-Bustos, H.; Pinto, M.C., Ávila, J.E. eta Vásquez, R. (2016): «TDAH con y sin ansiedad en niños: Caracterización clínica, sociodemográfica neuropsicológica», Revista Mexicana de Neurociencia, 17(3), 49-59. 
Presentación, M.; Pinto, V.; Meliá, A. eta Miranda, A. (2009): «Efectos sobre el contexto familiar de una intervención psicosocial compleja en niños con TDAH», Escritos de Psicología, 2(3), 18-26.

Raya , A.F.; Herreruzo, J. eta Pino, M.J. (2008): «El estilo de crianza parental y su relación con la hiperactividad», Psicothema, 20(4), 691-696.

Reynolds, C.R. eta Kamphaus, R.W. (2004): BASC: Sistema de evaluación de la conducta en niños y adolescents, TEA Ediciones, Madril.

Ríos-Flórez, J.A. eta López-Gutiérrez, C.R. (2018): «El rol de la neuropsicología y la interdisciplinariedad en la etiología y neurofuncionalidad del Déficit de Atención e Hiperactividad», Psicoespacios, 12(20), 73-93.

Rivera, F.B. (2016): «La elevada prevalencia del TDAH: posibles causas y repercusiones socioeducativas», Psicología educativa, 22(2), 81-85.

Roskam, I.; Stievenart, M.; Tessier, R.; Muntean, A.; Escobar, M.J.; Santelices, M.P.; ... eta Pierrehumbert, B. (2014): «Another way of thinking ADHD: The predictive role of early attachment deprivation in adolescents' level of symptoms», Social Psychiatry and Psychiatric Epidemiology, 49(1), 133-144.

Rubiales, J.; Bakker, L.; Russo, D. eta González, R. G. (2016): «Desempeño en funciones ejecutivas y síntomas comórbidos asociados en niños con Trastorno por déficit de atención con hiperactividad (TDAH)», Revista CES Psicología, 9(2), 99-113.

Rucklidge, J. eta Tannock, R. (2002): «Validity of the Brown ADD scales: an investigation in a predominantly inattentive $A D H D$ adolescent sample with and without reading disabilities", Journal of Attention Disorders, 5(3), 155-164.

Rygaard, N.P. (2008): El niño abandonado: guía para el tratamiento de los trastornos del apego, Gedisa, Bartzelona.

Sadek, J. (2019): «ADHD and Oppositional Defiant Disorder (ODD)», in J. Sadek (ed.), Clinician's Guide to ADHD Comorbidities in Children and Adolescents, Springer, Cham, 37-45.

Sanders, M.R.; Kirby, J.N.; Tellegen, C.L. eta Day, J.J. (2014): «The Triple P-Positive Parenting Program: A systematic review and meta-analysis of a multi-level system of parenting support», Clinical Psychology Review, 34(4), 337-357.

Santurde, E. eta Del Barrio, J.A. (2013): «TDAH: Intervenir en el Fomento del Apego», International Journal of Developmental and Educational Psychology, 1(1), 265270.

Santurde, E. eta Del Barrio, J.A. (2016): «Papel relevante de los estilos educativos en la evolución de los síntomas de TDAH». International Journal of Developmental and Educational Psychology, 1(1), 251-258.

Serrano-Troncoso, E.; Guidi, M. eta Alda-Díez, J.Á. (2013): «¿Es el tratamiento psicológico eficaz para el trastorno por déficit de atención con hiperactividad (TDAH)? Revisión sobre los tratamientos no farmacológicos en niños y adolescentes con TDAH», Actas Españolas de Psiquiatría, 41(1), 44-51.

Siegenthaler, R.; Presentación, M.J.; Colomer, C. eta Miranda, A. (2013): «Análisis de factores moduladores de la intervención psicosocial en preescolares con trastorno por déficit de atención/hiperactividad», Revista de Neurología, 56(1), 85-92.

Sonuga-Barke, E.J.S.; Thompson, M.; Daley, D. eta Laver-Bradbury, C. (2004): «Parent training for pre-school attention-deficit/hyperactivity disorder: Is it effective when delivered as routine rather than as specialist care?», British Journal of Clinical Psychology, 43(4), 449-457.

Sonuga-Barke, E.J.; Cortese, S.; Fairchild, G. eta Stringaris, A. (2016): «Annual Research Review: transdiagnostic neuroscience of child and adolescent mental disordersdifferentiating decision making in attention-deficit/hyperactivity disorder, conduct 
disorder, depression, and anxiety», Journal of Child Psychology and Psychiatry, 57(3), 321-349.

Storebø, O.J.; Rasmussen, P.D. eta Simonsen, E. (2016): «Association between insecure attachment and ADHD: environmental mediating factors", Journal of Attention Disorders, 20(2), 187-196.

Swanson, J.M. (2003): «SNAP-IV Teacher and Parent Rating Scale», in A. Fine eta R. Kotkin (edk.), Therapist guide to learning and attention disorders, Academic Press, New York, 487-500.

Thomas, R.; Sanders, S.; Doust, J.; Beller, E. eta Glasziou, P. (2015): «Prevalence of attention-deficit/hyperactivity disorder: a systematic review and meta-analysis», Pediatrics, 135(4), 994-1.001.

Thompson, M.J.; Laver-Bradbury, C.; Ayres, M.; Le Poidevin, E.; Mead, S.; Dodds, C.; ... eta Sonuga-Barke, E.J.S. (2009): «A small-scale randomized controlled trial of the revised new forest parenting programme for preschoolers with attention deficit hyperactivity disorder», European Child and Adolescent Psychiatry, 18(10), 605616.

Thorell, L.B.; Rydell, A.M. eta Bohlin, G. (2012): «Parent-child attachment and executive functioning in relation to ADHD symptoms in middle childhood", Attachment and Human Development, 14(5), 517-532.

Thurstone, L.L. eta Yela, M. (2012): Caras-R: test de percepción de diferencias-revisado, TEA Ediciones, Madril.

Webster-Stratton, C.H.; Reid, M.J. eta Beauchaine, T. (2011): «Combining parent and child training for young children with ADHD», Journal of Clinical Child and Adolescent Psychology, 40(2), 191-203.

Wechsler, D. (2008): Inteligencia General: Escala de Inteligencia de Wechsler para niños, WISC IV, TEA Ediciones, Madril. 

ERANSKINA: AGHNaren irizpideak DSM-Vren arabera.

A) Funtzionamenduan edo garapenean eragina du arreta-gabeziak edota hiperaktibitateinpultsibitateak.

A.1 Arreta-gabeziak: Hurrengo sintometatik 6 (edo gehiago) bete behar dira gutxienez 6 hilabetetan zehar.

- Xehetasunei arreta jartzeko zailtasuna eta hainbat ekintzatan hutsegiteak egiteko erraztasuna.

- Arreta mantentzeko zailtasuna.

- Entzuten ez duenaren sentsazioa.

- Argibideak jarraitzeko eta egin beharreko lanak amaitzeko zailtasunak.

- Antolatzeko zailtasunak.

- Esfortzu jarraitua eskatzen duten ekintzak saihestu.

- Gauzak galtzeko ohitura.

- Kanpo-estimuluak direla-eta distraitzeko joera.

- Eguneroko ekintzak ahazteko erraztasuna.

A.2 Hiperaktibitate-inpultsibitateak: Hurrengo sintometatik 6 (edo gehiago) bete behar dira gutxienez 6 hilabetetan.

- Eskuekin edo hankekin jolasteko ohitura.

- Eserita egotea espero den egoeretan, behin eta berriz altxatzea.

- Egoera desegokietan korrika eta saltoka ibili.

- Zailtasunak lasaitasunez jolasteko.

- Geldiezina. Motor batek bultzatuko balu bezala.

- Oso hiztuna.

- Galdera erantzun gabe erantzuteko joera.

- Zailtasunak bere txanda itxaroteko.

- Ingurukoak eragozteko ohitura.

A. Arreta-gabezia, hiperaktibitatea edota inpultsibitatea 12 urte baino lehen agertzen da.

B. Sintoma horietako batzuk, gutxienez, bi testuinguru desberdinetan beha daitezke.

C. Sintomek funtzionamendu pertsonalean, sozialean eta akademikoan eragiten dute.

D. Eskizofreniak, trastorno psikotikoek edo beste nahaste mentalek ez dituzte sintoma hauek azaltzen.

Iturria: DSM-V diagnostiko-irizpideen kontsulta gida (American Psychiatric Association, 2014). 
